\section{ORGANIZATIONAL JUSTICE AS A PREDICTOR OF CYBERLOAFING: A SURVEY RESEARCH}

\author{
Mr. Kiransinh Natwarsinh Rajput, Dr. B.S. Parimal \\ Assistant Professor \\ Department of Psychology, \\ Government Arts College Shahera, \\ Panchmahal \\ kiran_rajput2010@yahoo.com \\ Assistant Professor, \\ Department of Psychology, \\ Faculty of Education and Psychology, \\ The Maharaja Sayajirao University of Baroda, Vadodara
}

\begin{abstract}
Organizational Justice helps an organization to achieve ethical and legal standards. Organizational Justice means to what extent organization treats employees fairly and equally without bias. Globalization and technological change help organization for fast communication at the same time technological change also create challenges for an organization like cyberloafing. Cyberloafing means unproductive use of technologies at the workplace. The objective of the study is to investigate whether Organization Justice significantly predicts Cyber loafing. The total sample comprised of 276 employees from the manufacturing sector and the service sector. Organizational justice perception scale and Cyberloafing scale as standardized scales used for data collection and the researcher used the survey method. The result shows that distributive justice and interactional justice significantly negatively predict Cyberloafing and Procedural Justice no significantly predict cyberloafing. The finding will implicate in organizations to form polices minimizing cyberloafing behaviour at the workplace.
\end{abstract}

Keywords: Organizational Justice, Cyberloafing, Distributive justice, Procedural Justice and interactional justice Introduction

In today's world business environment is changing rapidly due to globalization, new technology, government policies, market competition, etc. Organizational justice contributes to positive organization behaviour like organizational citizenship behaviour, employee engagement, employee retention, etc. Organizational justice research addresses perceptions of fairness in organizational decisions and decision-making procedures. There are four types of organizational justice namely distributive justice, procedural justice, interpersonal justice and informational justice.

Distributive justice means employee's perception of the fairness of his or her outcomes, such as pay (Adams 1965). Distributive justice means fairness of the rewards and outcomes received and justice is perceived if rewards received are proportional to the input. (Adams \& Jex, 1999, Homans, 1961). MacFarlin and Sweeney (1992) concluded that the positive relationships of procedural justice with evaluation of supervisor and commitment were weaker when distributive justice is high than when it is low. Furthermore, procedural justice is found to be more positively related to an individual's reactions when outcome fairness is relatively low (Brockner, Wiesenfeld, 1996). Procedural justice refers to justice in the means by which distributions or decisions are made (Hegtvedt and Markovsky 1995). Employees generally consider means to be justice when those means allow consistency across individuals and time, suppression of bias, representativeness of the opinions of people affected, accuracy of information, mechanisms to correct bad decisions, and conformity with moral and ethical standards (Leventhal, Karuza, and Fry 1980).

Justice is a subjective perception so that it is quite difficult for organizations to found justice among the employees in absolute terms. Even if justice has been achieved in absolute terms, the perception of employees in this regard is developing in a negative direction, and employees can try to maintain justice in the organization on their own (Günay, Azizoğlu \& Çakar, 2018). Cyberloafing is ways of avoiding work and engage in unproductive work result from employees thinking to maintain justice on their own or for no reason. In organizations, the extensive use of technology, especially computers, has led to increased access to internet services and even to organizations becoming dependent on online technology (Günay, Azizoğlu \& Çakar, 2018). As a subjective concept, the sense of organizational justice is shaped as a result of employees' judgments compared to their past work, as well as the output they obtain from their contributions to the organization, compared with other people such as friends and colleagues (Robbins and Judge., 2012). The distributive justice expressed in terms of the benefits that employees receive in return for their contributions to the organization (İyigün 2012). The awards (or punishments) must be equal if the efforts made by the employees are equal for 


\section{GAP INDIAN JOURNAL OF FORENSICS AND BEHAVIOURAL SCIENCES ( ISSN - 2582-8177)}

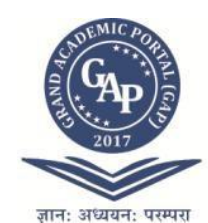

the enterprise (ÖzafşarlıoğluSakall, 2015). Interactional justice focuses on human relationships, unlike procedural and distributive justice (Özyer and Azizoğlu, 2014).

Lim (2002) introduced concept Cyberloafing as an anti-production aberrant behaviour. Gunay (2017) noted that because it causes a waste of resources based on Robinson and Bennett's (1995) typology of aberrant organizational behaviours, is defined as the use of digital equipment and on-line connection facilities that have been allocated for work purposes by employees for their consumption rather than productive utilization. Cyberloafing behaviour, which was included in the literature with the mere definition of personal e-mail activities and surfing on websites by Lim (2002), is now defined as a much wider array of actions due to the development of technology and the diversification of the services offered via internet. Many employees use smartphones and tablets in the aftermath of the development of communication types of equipment as well as communication technologies, and employees can show Cyberloafing behaviours by using these tools that belong to themselves (Arslan and Demir, 2016). Employee's behaviours intended to obtain information about the work of employees, increase productivity while the use of negative Cyberloafing will lead to a disadvantageous situation for the organization resulting from the abuse of resources (Aydemir et al., 2016) Trivial Cyberloafing includes short-term behaviors that do not affect the workflow and can be tolerated, while serious cyberloafing refers to behaviours that can put the employees themselves, manager and business in a legally or ethically difficult situation (Günay, 2017). There is a lot of serious example of Cyberloafing like playing illegal gambling online, entering adult sites, hacking, etc. Proost et al. (2015) says that organizational injustice increases stress and Lim and Chen (2012) and Ugrin and Pearson (2013) say that cyberloafing activities are good at reducing stress.

Lim (2002) found that Cyberloafing is used by employees as a neutralization technique. When employees perceive an injustice against their favour, they try to achieve justice by attempting cyberloafing. Blau et al. (2006) with the data obtained from 267 medical technology specialists registered and recently graduated from the American Society for Clinical Pathology found that experts demonstrated Cyberloafing behaviours in the case of perceiving an organizational injustice. De Lara (2007) concluded that work anomia has a mediating effect between organizational justice perceptions and cyberloafing behaviors. Zoghbi (2011) found there is a negative relationship between procedural justice as a sub-dimension of organizational justice and cyberloafing. Kaplan and Ögüt (2012) collected data from 198 university students in two university hospitals in Konya and concluded that there is a significant relationship between all sub-dimensions of organizational justice and cyberloafing behaviour and Cyberloafing behaviors are only negatively related to distributive justice. Yıldız et al. (2015) researched on 151 academic and administrative personnel and found that there is no significant relationship between employees' perceptions of organizational justice and cyberloafing. There is a significant negative correlation between perception of interactional justice and total organizational justice and cyberloafing behavior and that as the justice perception of employees increases, the cyberloafing behavior decreases (Günay, Azizoğlu \& Çakar, 2018). There is not a significant relationship between the dimensions of organizational justice and cyberloafing. (Akin,Ulukök \& Arar, 2017). Lim (2002) stated that when employees perceived their organizations to be distributive, procedurally and internationally unjust, they were likely to invoke the metaphor of the ledger as a neutralization technique to legitimize their subsequent engagement in the act of cyberloafing. Organisational trust mediated the correlation between organisational justice and work engagement while work engagement mediated the relationship between organisational trust and Cyberloafing (Oosthuizen, Rabie, G \& De Beer 2018).

A Review of literature doesn't show clearly that there is a significant negative correlation among subdimensions of organizational justice and cyberloafing. A maximum review of literature found there is a significant effect of organizational justice on cyberloafing. However, there is some review of literature concluded that there is no significant effect of organizational justice on cyberloafing. The current research aimed to study whether organizational justice significantly predicts cyberloafing.

\section{OBJECTIVES}

To study whether distributive justice significantly predict Cyberloafing

To study whether procedural justice significantly predict Cyberloafing

To study whether interactional justice significantly predict Cyberloafing

\section{HYPOTHESES}

Distributive justice will significantly predict Cyberloafing

Procedural justice will significantly predict Cyberloafing

Interactional justice will significantly predict Cyberloafing 


\section{GAP INDIAN JOURNAL OF FORENSICS AND BEHAVIOURAL SCIENCES ( ISSN - 2582-8177)}

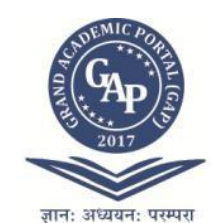

Cyberloafing $\quad-0.081$

1.32

0.91

$-0.081$

$-0.053$

$-0.047$

Note. ${ }^{* *} \mathrm{p}<0.01$ level . ${ }^{\mathrm{p}} \mathrm{p}<0.05$ level

Table 2 shows the values of Beta, $t$, ANOVA, and regression from the result of responses collected. There is no significant correlation between procedural justice and Cyberloafing ( $r(274)=-0.081, p>0.05)$. The result of independent $t$-test between the variables show no significant difference $(t=1.32, p>0.05)$. Extend of procedural justice viewed explain $5 \%$ of variance in the cyberloafing. The second hypothesis assumed that procedural justice will significantly predict cyberloafing. Hence the hypothesis is rejected. Review of literature supports the current finding. There is not a significant relationship among the dimensions of organizational justice and cyberloafing. (Akin,Ulukök \& Arar, 2017). There is no direct influence of organization justice on cyberloafing without mediation work anomia (De Lara, 2007). However, Zoghbi (2011) concluded that there is a negative relationship between procedural justice and cyberloafing.

Table 3 Regression analysis to study whether to study whether interactional justice significantly predict Cyberloafing

\begin{tabular}{lllllll}
\hline Variables & Beta value & t-value & F Ratio & $\mathrm{R}$ & $\mathrm{R} 2$ & Adjusted R2 \\
\hline Cyberloafing & -0.17 & $9.37^{* *}$ & $20.19^{* *}$ & -0.17 & -0.126 & -0.118
\end{tabular}

Note. ${ }^{* *} \mathrm{p}<0.01$ level $. * \mathrm{p}<0.05$ level

Table 1 shows the values of Beta, $t$, ANOVA, and regression from results of responses collected. There is a significant negative correlation between interactional justice and Cyberloafing ( $(274)=-0.17, p<0.01)$. The result of independent $t$-test between the variables shows a significant difference $(t=9.37, p<.01)$. Extend of distributive justice viewed explain $13 \%$ of variance in the cyberloafing. The result indicates that employees who perceived higher interactional justice in organization, they less engage in cyberloafing. The third hypothesis assumed that interactional justice will significantly predict cyberloafing. Hence the hypothesis is accepted. Previous researches have similar finding support the result. There is a significant negative correlation between perception of interactional justice and cyberloafing behavior and that as the justice perception of employees increases, the cyberloafing behavior decreases (Günay, Azizoğlu \& Çakar, 2018). Organisational trust mediated the correlation between organisational justice and work engagement while work engagement mediated the relationship between organisational trust and Cyberloafing (Oosthuizen, Rabie \& De Beer 2018). Lim (2002) stated that when employees perceived their organizations to be distributive, procedurally and internationally unjust, they were likely to invoke the metaphor of the ledger as a neutralization technique to legitimize their subsequent engagement in the act of cyberloafing. Equity theory on job motivation suggests that when employees perceived organization justice, their motivational level increases and they engage in positive organization behaviour and less engage in negative organization behaviour like cyberloafing (Adams, 1963). Blau et al. (2006) noted that there are Cyberloafing behaviours in the case of perceiving an organizational injustice.

\section{LIMITATIONS}

Samples were taken only from Vadodara and Panchmahal districts. Male employees' and female employees' proportion was not equal. Employees from manufacturing sector and employees from service sector proportion were also not equal.

\section{CONCLUSION}

Employees who perceived higher distributional justice in organization, they engage less in cyberloafing. There is no significant effect of procedural justice on cyberloafing. Employees who perceived higher interactional justice in the organization, they engage less in cyberloafing. Knowing the relationships between organizational justice and cyberloafing behaviour is useful to organizations and can provide them with additional information from which to base their forming policies to minimize cyberloafing and similar negative organization behaviour. It can conclude that distributive justice and interactional justice help organizations to decrease cyberloafing behaviour.

\section{REFERENCES}

[1] Adams, J. S. (1963). Toward an understanding of inequity. Journal of Abnormal and Social Psychology, 67, 422-436.

[2] Adams, J. S. (1965). Inequity in social exchange. In L. Berkowitz (Ed.), advances in experimental psychology pp. 267-299. New York: Academic Press 


\section{GAP INDIAN JOURNAL OF FORENSICS AND BEHAVIOURAL SCIENCES}

( ISSN - 2582-8177)

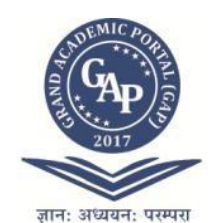

[3] Adams, J. S., \& freedman, S. (1976). Equity theory revisited: Toward a general theory of social interaction. Advances in Experimental Social Psychology, 9, 421- 436.

[4] Akin, A. ,Ulukök, E. \& Arar,T. (2017). Analyzing the Relationsip between Organizational Justice and Cyberloafing: A Study in a Public University. 4th Multidisciplinary Conference, Prague, Czechia, DOI: 10.19275/RSEPCONFERENCES088

[5] Arslan, E. T., \& Demir, H. (2016). Sanal Kaytarma: Bir Kamu Kurumunda Hemşireler Üzerinde Ampirik Bir Araştırma, The Journal of International Social Research, 9(43), 1626-1637.

[6] Aydemir, S., Korkmaz, O., \& Erdoğan, E. (2016). İş Yaşamında Sanal Kaytarma: Kamu ve Özel Hastane Çalışanları Üzerinde Bir Araştırma, Sosyal Bilimler Metinleri, 2016(1), 48-52.

[7] Blau, G., Yang, Y., \& Ward-Cook, K. (2006). Testing A Measure of Cyberloafing, Journal of Allied Health,35(1), 9-17.

[8] Brockner, J., \& Wiesenfeld, B. M. (1996). An integrative framework for explaining reactions to decisions: Interactive effects of outcomes and procedures. Psychological Bulletin, 120(2), 189208. https://doi.org/10.1037/0033-2909.120.2.189

[9] De Lara, P. Z. M. (2007). Relationship between organizational justice and cyberloafing in the workplace: Has "anomia" a say in the matter?. CyberPsychology \& Behavior, 10(3), 464-470.

[10] Günay, M. (2017). 21. Yüzyılda örgütsel davranış.Polatcı, S. ve Özyer K. (Ed.). İstanbul:Beta Yayınları.

[11]Günay, M., Azizoğlu, O. \& Çakar, S. (2018). The Effect of Perceived Organizational Justice on Cyberloafing Behavior. Paper presented at International Conference on Contemporary Issues in Business And Economics (Iccibe), At Tokat / Turkey. Retrieved on June 5, 2020, from https://www.researchgate.net/publication/331412059

[12] Hegtvedt, K. A., and Markovsky, B. (1995). Justice and injustice. In Cook, K. S., Fine, G. A., and House, J. S. (eds.), Sociological Perspectives on Social Psychology, Allyn and Bacon, Boston, pp. 257-280.

[13]Homans, George C. (1961) Social Behaviour: Its Elementary Forms. New York: Harcourt, Brace \& World, Inc.

[14] İyigün, N. Ö. (2012). Örgütsel adalet: Kuramsal bir yaklaşım. İstanbul Ticaret Üniversitesi Sosyal Bilimler Dergisi. 11(21), 49-64.

[15] Kaplan, M., \& Öğüt, A. (2012). Algılanan Örgütsel Adalet ile Sanal Kaytarma Arasındaki İlişkinin Analizi: Hastane Çalışanları Örneği, Dokuz Eylül Üniversitesi İşletme Fakültesi Dergisi, 13(1), 1-13.

[16]Lee, Z., Lee, Y., \& Kim, Y. (2004). Personal Web usage in organizations. In M. Anandarajan \& C. A. Simmers (Eds.), Personal web usage: A guide to effective human resources management (pp. 28-45). Hershey, PA: Information Science Publishing.

[17] Leventhal, G. S., Karuza, J., and Fry, W. R. (1980). Beyond fairness: A theory of allocation preferences. In Mikula, G. (ed.),Justice and Social Interaction Springer-Verlag, New York.

[18]Lim, V. K. G., \& Teo, T. S. H., (2005). Prevalence, perceived seriousness, justification, and regulation of cyberloafing in Singapore: An exploratory study. Information and Management, 42, 1081-1093.

[19] Lim, V. K. G., \& Teo, T. S. H., (2006). Cyberloafing and organizational justice: The moderating role of neutralization technique. In M. Anandarajan, T. S. H. Teo, \& C. A. Simmers (Eds.), The Internet and workplace transformation: Advances in management information systems (pp. 241-258). Armonk, NY: M. E. Sharpe.

[20] Lim, V. K. G., (2002). The IT way of loafing on the job: Cyberloafing, neutralizing, and organizational justice. Journal of Organizational Behavior. 23, 675-694.

[21]Lim, V. K. G., Chen, D. J. Q. (2012). Cyberloafing at the Workplace: Gain or Drain on Work, Behavior \& Information Technology, 31 (4), p. 343-353.

[22] McFarlin, D.B. and Sweeney, P.D. (1992) Distributive and Procedural Justice as Predictors of Satisfaction with Personal and Organizational Outcomes. Academy of Management Journal, 35, 626-637. http://dx.doi.org/10.2307/256489

[23] Niehoff, B. P., \& Moorman, R. H. (1993), Justice as a Mediator of the Relationship Between Methods of Monitoring and Organizational Citizenship Behavior, Academy of Management Journal. 36(3), 527-556.

[24] Oosthuizen, A., Rabie, G.H., \& De Beer, L.T. (2018). Investigating cyberloafing, organisational justice, work engagement and organisational trust of South African retail and manufacturing employees. SA Journal of Human Resource Management/SA Tydskrif vir Menslikehulpbronbestuur, 16(0), a1001. https://doi.org/ 10.4102/sajhrm.v16i0.1001

[25]Örücü, E., \& Yıldız, H. (2014). İşyerinde Kişisel İnternet ve Teknoloji Kullanımı: Sanal Kaytarma, Ege Akademik Bakıș, 14(1), 99-114.

[26] Özafşarlıoğlu Sakallı, S. (2015). Örgütsel adalet ile örgütsel güven ilişkisinde kişilik özelliklerinin düzenleyici rolü ve bir alan araştırması, (Yayımlanmamış Dokora Tezi). Balıkesir Üniversitesi, Balıkesir.

[27] Özyer, K., \& Azizoğlu, Ö. (2014). İş hayatında kadınların önündeki cam tavan engelleri ile algılanan örgütsel adalet arasındaki ilişki. AİBÜ-İİBF Ekonomik ve Sosyal Araştırmalar Dergisi.10 (1), 95-106.

[28] Proost, K., Verboon, P., Ruysseveldt, J. V. (2015). Organizational Justice as Buffer against Stressful Job Demands, Journal of Managerial Psychology, 30 (4), p. 487-499.

[29] Robbins, S. P. \& Judge, T. A. (2012). Organizational Behavior. İnci Erdem (Trans. Ed.), Örgütsel Davranış. 
Ankara: Nobel Publishing.

[30]Robinson, S. L. \& Bennett, R. J. (1995). A Typology of Deviant Workplace Behaviors: A Multidimensional Scaling Study, Academy of Management Journal, 38, 555-572.

[31]Ugrin, J. C., Pearson, J. M. (2013). The Effects of Sanctions and Stigmas on Cyberloafing, Computers in Human Behavior, 29, p. 812-820.

[32]Yıldız, H., Yıldız, B., \& Ateș, H. (2015). Sanal kaytarma davranışlarının sergilemesinde örgütsel adalet algısının rolü var mıdır?. Bilgi Ekonomisi ve Yönetimi Dergisi, 10(2), 55-66.

[33]Zoghbi Manrique de Lara, P. (2011). Reconsidering the boundaries of the cyberloafing activity: The case of a university. Behaviour \& Information Technology, 37(1), 1- 1. 